Article

\title{
The Sacrament of Revelation: Toward a Hermeneutics of Nuptial Encounter
}

\author{
Lauren Smelser White \\ College of Bible \& Ministry, Lipscomb University, Nashville, TN 37204, USA; lauren.white@lipscomb.edu
}

Received: 11 July 2019; Accepted: 18 August 2019; Published: 22 August 2019

\begin{abstract}
This article addresses the notion of sacramentality in relation to revelation, framing revelation as a divine-human discursive encounter facilitated through semantic media. In doing so, it suggests disciplines for theological reflection that would preserve the import of human submission to the Holy Spirit's guidance in interpreting God's Word while also envisioning a positive place for subjective construction along that Spirit-led way. The article locates the basic tenets of such a methodological paradigm in the works of Sarah Coakley, Louis-Marie Chauvet, and Rowan Williams. Coakley's work provides the groundwork for a vision of ecstatic encounter with God as integral to the Spirit-led process of revelation. Next, engagement with Chauvet establishes how mediated revelation may be conceived as a sacramental and dialogical reality, which fundamentally evokes and includes human self-expression. The article closes by drawing upon Williams' theological reflection on sexuality as a resource for embracing subjective construction, as integral to our Spirit-guided, "nuptial" incorporation into the life of Christ. The results afforded by this analysis warrant spiritual-hermeneutic commitments from communities who desire to cooperate with the Holy Spirit in acts of theological interpretation.
\end{abstract}

Keywords: revelation; sacrament; hermeneutics; Holy Spirit; Pneumatology; spirituality; symbol; ekstasis

\section{Introduction}

Christianity is experiencing a revival of the Holy Spirit. This is true not only in the church, which is seeing the striking growth of Pentecostal-charismatic movements in the global South, but also in academic circles, where there is burgeoning interest in fresh engagements with Pneumatology. ${ }^{1}$ Regarding the latter trend, in his plenary address to the 2007 Nordic Systematic Theology Conference (whose theme was "Spirit and Spirituality"), LeRon Shults offered this incisive observation:

The one trend in contemporary Pneumatology that encompasses virtually all of the others is the trend represented in the very title of this conference: Spirit and Spirituality. Broadly speaking, the theme of spirituality deals with the ways in which we interpret and attend to the transformation of our relation to God and our neighbors. Most of the general developments—and many of the concrete proposals-in recent Pneumatology are oriented toward or flow out of this concern. (Shults 2007, p. 1)

On the face of things, the close relation of Pneumatology and spirituality may seem obvious: it would appear that theologians' giving formal attention to Christian spiritual experience would lead them quite

1 Specifically, for instance, as LeRon Shults remarked in his 2007 address to the Nordic Systematic Theology Conference, there is "growing interest in and generative use of the theological concept of the divine Spirit among those exploring issues in feminist and liberation theology, ecology, politics, ecumenism and the astonishing expansion of Pentecostalism" (Shults 2007, p. 1). 
naturally into considering and constructing treatises on the topic of the Holy Spirit. But, in fact, this has not long been the case for contemporary academics, as Shults reminds his audience: the corpus of post-Enlightenment academic theology instantiates a marked gap between attention to spiritual practice and systematic treatments of the Holy Spirit. This fact is little wonder, given that, over the course of modernity, Christian spirituality had become predominantly circumscribed within the bounds of inner, individual states of psychological or transcendental experience. ${ }^{2}$ It is only in the past eighty years or so that a robust body of academic literature began to expand that acknowledges, and demonstrates interest in mining, the overlap of Christian spirituality and theology in general. That movement-made possible largely by the work of the New Theology (nouvelle théologie) theologians, ${ }^{3}$ and propelled by innovative figures like Simone Weil and Hans Urs von Balthasar-apparently succeeded because it shifted away from individualist, psychological framings of spiritual experience and instead situated spirituality in the contexts of liturgical practice, trinitarian faith, and the cooperation of nature and grace. $^{4}$

The present essay's analysis represents an effort to honor the wisdom borne out in attending to spirituality in those three contexts. It seeks to do so specifically in the interest of unearthing practical implications for Spirit-guided hermeneutics, having conceived "spirituality" as does Shults-i.e., as the interpretation of and attention to transformed relations to God and neighbor. The essay works towards this goal by synthesizing certain intriguing contributions of three thinkers who have recently theologized at the intersections of systematics and spirituality: Sarah Coakley (looking closely at her recently acclaimed God, Sexuality, and the Self, 2013), Louis-Marie Chauvet (by way of his seminal work Symbol and Sacrament, 1987), and Rowan Williams (attending to his celebrated essay "The Body's Grace," 2002). In three broad moves, this engagement distills a pneumatological paradigm as a departure-point for framing mediated revelation as a sacramental event, which event presses toward what I call a "hermeneutics of nuptial encounter." First, it assesses Coakley's integration of Pneumatology and spiritual disciplines, drawing out key implications and questions vis-à-vis a doctrine of revelation. Second, the essay considers how those questions are illumined by the concept of sacramentality as articulated by Chauvet, thereby proposing how inspired revelation may be conceived as the occasion and outcome of a divine-human discursive encounter. Having thematized this rendering of revelation, the essay's third move takes up Williams' theological reflection on sexuality, thus suggesting how revelation as sacrament concurs with our "nuptial" incorporation into Sonship. The essay concludes by calling for a hermeneutics that accounts for the spiritual insights afforded by this constructive synthesis, which ultimately results in a proposal for theological method. Let us now turn to its first broad move.

\section{Sarah Coakley and the "Spirit-Led" Experience of Mediated Revelation}

In a memorable segment of God, Sexuality, and the Self (2013), Coakley takes issue with trinitarian formulae that she evaluates as relying upon something like a "linear' revelatory model," wherein "primary focus is given to the Father-Son relationship, and the Holy Spirit becomes the secondary purveyor of that relationship to the church" (p. 11). Coakley finds such a rendering of the trinitarian relations paradigmatically represented in the Gospel of John, wherein the Father-Son/Logos bond is prominent in Christ's earthly life, and the Spirit comes to "replace [Christ] and to remind the

2 Spirituality came to be defined largely according to inner psyschological states under the significant impact of William James' Varieties of Religious Experience (1902), wherein James influentially asserted both the possibility and benefit of setting aside philosophical and theological concerns when analyzing religious experience. In theological sectors, this bifurcation of spiritual experience and theological interpretation was largely accepted by neoscholastic Thomists, whose "natural theology" envisioned an inherent division between divine activity and natural human experience; meanwhile, it was also accepted by transcendental Thomists who (in the vein of Schleiermacher) framed spirituality in the terms of pre-thematic, transcendental experience. For detailed analysis of this twofold development in Thomistic thought, see McCool (2002).

3 Including, for instance, the work of such thinkers as Henri de Lubac, Marie-Dominique Chenu, and Yves Congar.

4 See Anselm Stolz's (Stolz [1938] 2001) ground-breaking argument along these lines in The Doctrine of Spiritual Perfection, trans. Aidan Williams (1938; New York: Crossroad/Herder, 2001), chp. 9, "Mystical experience." 
disciples of his teaching, after he has 'gone away' ... The Spirit's role here is to 'glorify' the Son by (secondarily) passing on his teaching and 'declaring' it to the disciples (John 16. 14)" (ibid., p. 101, fn. 1). In contrast with this linear model, Coakley argues for the importance of a "Spirit-led" model of God's self-disclosure as trinitarian, drawn paradigmatically from the contemplative prayer experience described in Romans 8: 15-27. In this passage, Coakley observes, "the priority ... logically and experientially speaking, is given to the Spirit" (p. 112), namely in that the pray-er who finds the Spirit "interced[ing] with sighs too deep for words" (vs. 26, NRSV) detects the Spirit's promptings "reflexively" at work" within her, drawing her own expressed longings into the "circle of response to the Father's call" (Coakley 2013, p. 111), enabling us to echo Christ's own call: "Abba! Father!" (vs. 15). Otherwise said: by way of sensing the Spirit's activity within her, galvanizing her own response to the draw of divine desire, the contemplative is able to detect a distinctive reflexivity in God's life-a perpetual outgoing and return of divine desire-which she begins to detect as the perichoretic dynamism of the trinitarian life itself. ${ }^{5}$ What's more, Coakley notes, this person who prays in the Spirit also finds that the Spirit's cooperative dynamism is "the primary means of incorporation into the trinitarian life of God" (p. 111): when she invites and accepts the Spirit's divine reflexivity via spiritual acts, she finds her own Christoform life made possible. Hence, the Holy Spirit does not simply point the believer to what has already been disclosed in the Father-Son bond. Rather, the Spirit's indwelling and incorporating activity constitutes the very experience whereby believers become aware simultaneously of God's existence as triune and their own experience of incorporation into God's life as "Sons."

Coakley takes care to note that the linear and the Spirit-led models of trinitarian revelation are neither at odds with nor even necessarily distinct from one another. They can be seen as "presum[ing] each other, given their close contiguity and entanglement within the texts of the New Testament" (p. 111). ${ }^{7}$ The crucial point she works to demonstrate, however (by closely examining the Trinity doctrine's historical development), is that when believers privilege the "linear" type of revelation, they tend to overlook-and neglect attending to, in practice-the Spirit's function as "that without which there would be no incarnated Son at all, and-by extension-no life of Sonship into which we, too, might enter by participation" (p. 56). Accordingly, Coakley finds reason in Paul's theology for emphasizing the Spirit's function as the primary initiator of the Son's being in the world. ${ }^{8}$ In this "Spirit-led" trinitarian paradigm, Coakley proposes that we may think of the "Father" as "both 'source' and ultimate object of divine desire," the "Spirit" as "that (irreducibly distinct) enabler and incorporator of that desire in creation - that which makes the creation divine," and the "Son" as "that divine and perfected creation" (p. 114).

The Spirit-led paradigm augurs intriguing implications not only for a doctrine of trinitarian revelation, but for mediated revelation in general. We can locate its touchstones in Coakley's treatment of the Romans 8 theme of the believer's Spirit-afforded incorporation into Sonship. Here, as the Spirit labors to impart the Christoform shape of life to those who pray, Jesus Christ remains Sonship's

5 Coakley explains it thus: "It is not that the pray-er is having a conversation with some distant and undifferentiated deity, and then is being asked (rather arbitrarily) to 'hyposticize' that conversation (or 'relationship') into a 'person' (the Spirit); but rather, that there is something, admittedly obscure, about the sustained activity of prayer that makes one want to claim that it is personally and divinely activated from within, and yet that that activation (the 'Spirit') is not quite reducible to that from which it flows (the 'Father')" (p. 112).

6 My regular use of the language of the believer's participation in "Sonship"—and, here, her status as "Son" - takes a cue from Coakley's use of the same language, drawn from Romans 8. I understand the language as she does: not as indicating a masculinized identity or status, but as referring to the believer's redemption via being "conformed to the likeness of [the] Son" (Romans 8:29, qtd. in Coakley 2013, p. 112).

7 Coakley notes that a tendency to prioritize one model over the other "arose partly and originally ... from an intrinsic ambiguity in the biblical resources for the later, developed, trinitarian thinking. For the 'ordering' of the language of Father, Son, and Spirit is varied in the biblical witness" (p. 101).

8 It is worth noting that one may also find basis in the Gospels for the Son's worldly existence being Spirit-initiated. Consider, for instance, at the Annunciation scene in the first chapter of Luke, when the angel Gabriel declares to Mary that the Holy Spirit will bring about her pregnancy (see also Matthew 1:18). 
supreme and orienting expression (the "divine and perfected creation," as Coakley says). Nevertheless, Coakley notes that-as this contemplative "groans" in the Spirit, moving agonistically toward her Christoloform goal—she discovers that "the whole creation has been groaning in labor pains" under the Spirit's influence as well (vs. 22). Hence,

the life of 'Sonship' ... is not only not restricted to Jesus's human (male) life, but nor to the mystical 'body of Christ' which is the church; it is ... expanded even further to include the full cosmological implications of the incarnation, the whole creation 'groaning' to its final Christological telos in God (Romans 8: 18-21). What this underscores is the extraordinary ripple effect of prayer in the Spirit-its inexorably social and even cosmic significance as an act of cooperation with, and incorporation into, the still extending life of the incarnation. (Coakley 2013, p. 114)

In sum, as the contemplative prays in the Spirit, she detects the cosmic reach of the Spirit's ministry of incorporation, which highlights the nature of the Incarnation as "still extending" and the believer's participation in that unfolding life as she is incorporated into it. The Spirit-afforded bestowal of Christocentric revelation does not involve believers' reception of something like a "closed text," in other words. It took its definitive shape in the life, death, and resurrection of Jesus Christ, but it is still unfolding in the cosmic expanse of history, its meaningful contours arising out of concrete contexts wherein the Spirit is drawing all things to their Christological telos. Those who pray in the Spirit should expect to find, then, that "the authority of the revelatory Word is continually and freshly encountered and expounded-by a 'reason' which is itself in process of disclosure" (ibid., p. 88, emphasis added).

In her earlier work Powers and Submissions (2002), Coakley had already hinted at the character of this "reason-in-process" vis-à-vis a "deepening of vision" afforded by contemplative exercises: when taking up the process of wordless prayer, the contemplative commonly experiences "a profound sense of the mind's darkening, and of a disconcerting reorientation of the senses" (p. 19). This unsettling experience is both the cost and benefit of a "love affair with a blank', such as contemplation is," Coakley says: costly, because it entails "a strange subversion of all certainties, a stripping, often painful, of what one previously took for granted" (p. 342) ${ }^{9}$, but also beneficial, because-as one suspends one's rational agendas and waits for what may be disclosed- "what fills the waiting over time is a kind of seepage in the self, a recognition of rich unconscious elements, a transcendence of narrow rationality" (ibid.).

Coakley also identifies a hallmark of the Spirit-afforded supercession of narrow rationality in the discovery that "twoness, one might say, is divinely ambushed by Threeness" (Coakley 2009, p. 11). Sinful dichotomies-for instance, those accompanying certain formulations of gender or race-are thereby granted "an eschatological hope," an expectation that "what is fallen can be redeemed and sanctified-indeed rendered sacramental by participation in Christ" (Coakley 2002, p. 54). This transformation of "twoness" is, indeed, sacramental; for it is typified in the hypostatic union, as Coakley sees it:

In Christ, I meet the human One who, precisely in the Spirit, has effected ... interruptive transfiguration of twoness. He has done so by crossing the boundary between [a] 'twoness' more fundamental even than the twoness of gender: the ontological twoness of the transcendent God and the created world. In crossing that boundary in the incarnation, Christ does not re-establish the boundary as before, nor—significantly—does he destroy it; rather, we might say that he 'transgresses' it in the Spirit, infusing the created world anew with divinity. (Coakley 2013, p. 57)

9 Coakley attributes the phrase "A love affair with a blank" to Dom Sebastian Moore (1977) description of contemplative practice in his "Some Principles for an Adequate Theism," Downside Review 95 (1977), pp. 201-13. 
Hence, interpreters of revelation should also expect that, as the Holy Spirit infuses creation with the conditions of the sacramental, it also works towards the "transgressing" - though not necessarily the undoing — of ontological boundaries, towards the end of relational intimacy.

Coakley cites (what we could take to be) an example of and entry-point into the sacramental transfiguration of twoness by way of Pseudo-Dionysius's Divine Names-particularly his use of the notion of ekstasis, the profound experience of self-opening that involves "an implicit acknowledgement of love across difference" (ibid., pp. 316-17). ${ }^{10}$ Dionysius, Coakley notes, attributes "ecstatic yearning not only to human lovers of God, but also, prototypically, to divine love of creation" (p. 314). The divine ekstasis may be understood as the incorporative reflexivity of the trinitarian life, the out-going and return of divine love that draws creation relationally towards Godself. For Dionysius, a similar ecstatic potential holds true between human parties; and while he may not have been thinking particularly of male-female relations, Coakley wonders what may come of applying his thinking on ekstasis in this context: "If the divine ecstasy returning to itself allows redeemed creation to participate in it, and so signals an 'incorporative' trinitarianism," she muses, "what, correlatively, might be the trinitarian implications of ecstatic love between the sexes?" (p. 317).

In a creative exposition upon that correlation, Coakley draws upon French theorist Luce Irigaray's thematizing of "the transcendence of the other which becomes an immanent ecstasy" in the act of love-making. ${ }^{11}$ Coakley reflects upon how, analogously, we may imagine that

human ecstatic loves (at their best) might ultimately relate to divine ecstatic love: not by any direct emulation of the trinitarian nature, but by the 'interruption' by the Spirit of any merely 'egological' duality inherent in their relationship, such that the human lovers are themselves aware of a necessary 'third' between them-both uniting them and protecting their integrity in their new ecstasy of exchange. What then is happening may even be a degree of participation in the divine life; but it comes with both the cost and the joy of truly 'ecstatic' attention to the other. (p. 318)

Coakley thus proposes not a lived entry-point into cooperating with the Spirit's incorporative dynamism - that is, a way of inviting sacramental union with God: by cultivating self-other distinction in relationship (whatever the cost) and enjoying that distinction to the point of its overturning. In that experience of ekstasis, one's perception is drawn not toward illuminated and fixed essences, but toward intimate embrace and noetic transformation. Entering into such relationship can teach us a way of stepping "willfully into an act of reflexive divine love that is always going on, always begging Christomorphic shape" (p. 343).

Even as this Christomorphic shape is ever arising, our theological reason remains ever in via, laboring towards its final telos of perfected union with God and neighbor. Coakley thus maintains that it is not possible (pre-eschaton) to guard absolutely against the danger of doctrinal language being impacted by "abuse and distortion" (p. 343). Hence, the hermeneutics of suspicion must always remain in play, keeping the socially-located and political complexion of contemplation and theological expression in view; and both the message and the structure of the church must remain open to amendment- though, notably, extant ecclesial structures ought not be reduced to rubble. While "authoritarian ecclesiastical Christian 'orthodoxy'" must not remain "cut off from the real 'sea' of lived religion by hierarchical avoidance or denial" (p. 72), says Coakley, there remains a practical

10 Coakley is looking at chapter 4, section 13 of Divine Names.

11 She draws upon a passage from Luce Irigaray's work wherein Irigaray is describing "the transcendence of the other which becomes an immanent ecstasy" in the act of love-making, as a "shared outpouring" and a "loss of boundary of the skin into the mucous membranes of the body, leaving the circle which encloses my solitude to meet in a shared space, a shared breath ... In this relation," Irigaray goes on, "we are at least three, each of which is irreducible to any of the others: you, me and our creation [oeuvre], that ecstasy of ourself in us [de nous en nous] ... prior to any 'child"” (Irigaray 1991, "Questions to Emmanuel Lévinas: On the Divinity of Love," in Robert Bernasconi and Simon Critchley, eds., Re-Reading Lévinas. London: Athlone, 1991. 109-18, at 88); quoted in Coakley (2013). 
and even ethical necessity in some sort of hierarchizing in the human realm if we are to order our values properly. ${ }^{12}$ It is oppressive hierarchies that we must cooperate with the Holy Spirit in seeking to overturn. In the end, the revelation-paradigm emerging from Coakley's work is fundamentally practical, one of "knowing by doing"-but the "doing" encompasses more than simply taking up traditional disciplines, or simply challenging them. Those who wish to render their perceptions labile to the Spirit's direction must enter into a patient, lifelong enterprise of ascetic practice (which, as she frames it, uniquely enables one's commitment to justice ${ }^{13}$ ), ekstatic attention (to "the other" in every relational context), and continued discernment (of unfolding, Christomorphic reason), individually and corporately. Under the influence of such ongoing efforts, interpretive communities may embrace the painstaking processes of theological and liturgical retrieval and refinement in expectation that "what is fallen can be redeemed and sanctified—indeed rendered sacramental" by the Spirit's transfiguring ministry (Coakley 2002, p. 54).

In Coakley's estimation, there is no surer way to take up this work than by embracing the "slow but steady assault on idolatry which only the patient practices of [non-discursive] prayer can allow God to do in us" (Coakley 2013, p. 325). Granted, she does allow that "symbolic bombardment," such as that characterizing the trinitarian tradition's numerous metaphors for the Godhead, "should not be seen merely as a theological problem" (ibid., p. 309). In keeping with the tradition of the kataphatic/apophatic dialectic, "metaphorical profusion can aid, just as much as distract from, the epistemic stripping necessary to right contemplation of the divine," says Coakley (ibid.). "We can start with ... outrageous multiple cultural meanings and move, through contemplative purgation, to an ascetic alignment with God's purposes." As this progressive sacrifice of "cultural meanings" ministers toward the purgation not only of the contemplative's will, but also of her intellect, it ultimately "contribut[es] to an expanded objectivity of standpoint, rather than an intensified subjectivity" (p. 26). Coakley thus highlights the revelatory value of the kataphatic/apophatic process as a discipline that invites the Spirit's transfiguring influence. One may question, however, Coakley's foremost association of "symbolic bombardment" and "multiple cultural meanings" with the need for purgative silencing rather than also with potential for facilitating communion with God. It is difficult to see how language is "rendered sacramental" within this formulation.

Coakley does highlight the sacramental potential, so to speak, that exists in certain communicative forms when she attends to artistic representation of the Trinity that "(in its most creative and original moments) point[s] out beyond literalism and ideology to something both richly symbolic and at the same time apophatic in its imaginative dimensions" (ibid., p. 260). She thus emphasizes the latent possibility in certain forms of dialogic expression-namely, here, in the representative mode of the visual arts- to hold together kataphatic and apophatic import, sacramentally weaving physical and spiritual together. Nonetheless, Coakley's "love affair with a blank" - that is, her steady emphasis on wordless prayer and silent contemplation as primary means of opening ourselves to the Spirit's transforming influence-seemingly exhibits a rather low view of our less creative, everyday semantic tendencies. They apparently number among the fallen realities that, if they need not be eliminated altogether, must become thoroughly subject to non-discursive discipline so as to be rendered sacramental. Could there be a sense in which our dialogic ${ }^{14}$ expression itself may become a sacramental site of communion

12 On this point Coakley refers to anthropologist Louis Dumont's underscoring of the necessity of a "system of ordered values" for social life, as well as to Mary Douglas's work on cultural analysis. Therein, Douglas points out that the "'hierarchical society' is not necessarily, let alone intrinsically, a repressive top-down system," but can be one wherein "'every decision is referred to the well-being of the whole ... transcending its parts'"' (p. 320).

13 Coakley says: "there is much talk of the problem of attending to the otherness of the 'other' in contemporary post-Kantian ethics and post-colonial theory; but there is very little about the intentional and embodied practices that might enable such attention.... The moral and epistemic stripping that is endemic to the act of contemplation is a vital key here: its practiced self-emptying inculcates an attentiveness that is ... more discomforting, more destabilizing to settled presuppositions, than a simple intentional design on empathy" (p. 48).

14 I am here employing the notion that all language is dialogical, endlessly responsive to what has already been said and in anticipation of what will be said in turn. 
with the divine? The remainder of this essay works to develop such an account of communicative acts, locating the basic tenets of such a paradigm in Louis-Marie Chauvet's work with the notions of sacrament and symbol. In its light, we may begin to see how subjective human construction can be integral to the Spirit-led unfolding of Christic revelation. Let us turn now to identify those tenets.

\section{Louis-Marie Chauvet and the Sacrament as Dialogical Occasion}

One avenue of entry into Chauvet's theological endeavor in Symbol and Sacrament is by way of his engagement with Karl Barth therein. Chauvet affirms Barth's positions that "the Word of God is sovereign, that this Word gathers in Christ the entire unfolding of history," and that the visible church's status as Christ's body is a fact undergirded by mystery (p. 540). Chauvet expresses reservations with Barth's project, however, on the grounds that Barth has (ironically) reached too far with his mode of theologizing, which implies that the human can contemplate reality from some ahistorical, extemporal perspective. ${ }^{15}$ To avoid this perceived error Chauvet affirms that, while the Christ-event certainly constitutes an "eschatological rupture" in history, that rupture must not entail the utter discontinuity "between 'profane' history and 'salvation' history" (p. 546). Instead, Chauvet believes that the sacred-profane distinction ought to be treated as fluid, for the Word became flesh; it did not simply "live in" the body as an instrumental organ. In keeping with this premise, and the fact that the flesh of the Word is necessary for our encounter with it-we could not and cannot conceive it otherwise- - one of Chauvet's key proposals is that God's Word appropriates the human symbolic nexus, not as a "veil concealing the unique divine action" but rather as a sacred space of relational encounter between God and humanity (p. 539). For Chauvet, divine revelation unfolds as we are grasped by it in the mediating spaces of our historically, ethically, and symbolically constituted and constituting embodiment. Accordingly, we should see the entire corporeal realm, including language, as an "arch-sacramental" medium of grace. ${ }^{16}$

Maintaining this view of the corporeal nexus as a site of divine-human encounter, Chauvet establishes his basic purpose in Symbol and Sacrament: rather than subsuming the Christian sacraments into an abstract notion of "sacramentality," he wants to consider them as "symbolic figures allowing us entrance into, and empowerment to live out, the (arch-)sacramentality which is the very essence of Christian existence" (p. 2, italics in original). He believes that proceeding along these lines requires shifting away from the Scholastic metaphysical approach to the sacraments, which, broadly construed, conceptualizes them in terms of causality. To explain: unlike Barth's approach to human signification (which, for Chauvet, over-determines that system's deficiency), Chauvet critiques Scholastic thinking for presuming a natural capacity in the signifier to touch or even produce the reality it signifies. That thinking accordingly conceives of the sacraments "instrumentally," that is, as signifiers inherently able to affect the realities they indicate, however mysteriously (see Boeve 2008, p. 7). Chauvet resists this instrumentalist approach to the sacraments on the grounds that it fails to recognize humanity's essential constitution "inside language": any presence we encounter via the system of signification always operates in tandem with its absence, its "going beyond" language. ${ }^{17}$ He roots this argument in Martin Heidegger's existential philosophy, according to which "humans do not possess language," as Chauvet explains it; "rather, they are possessed by it. They speak only because they are always-already spoken" (p. 57,

15 Chauvet connects his critique to an observation by H. Bouillard: "What bothers us the most is precisely that Barth has somehow placed himself in God's unique vantage point ... in order to contemplate God's work from that vantage point" (quoted in Chauvet 1995, p. 540).

16 I previously engaged these hermeneutic features of Chauvet's work in (White 2016). In that article I considered in greater detail the epistemological implications of his work as an expression of a critically realist ontology, whereas here I engage in greater detail the theological import of his depiction of the human situation within language.

17 Chauvet operates with a broadly construed notion of "language": as the verbal and non-verbal web of signifiers. Though I cannot take up the task here, I believe Chauvet's critique of Thomas Aquinas (though perhaps not later Scholasticism) on these accounts warrants nuance: the Thomistic deployment of analogy could be seen as preserving the eschatological quality of theological utterance within a symbolic register. 
italics in original). Chauvet also affirms Heidegger's observation that metaphysics mistakenly "believes itself to have produced an explanation of being, when in fact it has only ontically reduced being to metaphysics' representations, utterly forgetting that nothing that exists 'is'" (pp. 26-27). We cannot, then, instrumentally reach or bring about realities untouched by the system of signification, for that system is indelibly constitutive of our perception. The fact that we lack foolproof understanding of what becomes present to us via that system might be overlooked by frameworks such as that of analogical negation (which could be taken as circumventing the distressing reality of God's absence/unknowability). Chauvet finds such projects to be hazardous, for presuming that we can plot even the "fixed" nature of reality's withdrawal from language can render theology an idol of speculation.

Arguing in the above fashion, Chauvet proposes that if we imagine our interpretive engagement with the sacraments as existing in plottable connection or contrast with an external reality, we will take up those discourses in self-deception, laboring to construct "short-cut onto-(theo)logical approaches" in fear of "the consequences of a fully hermeneutical theology" (p. 23). From a "fully hermeneutic" theological perspective, we would contemplate the nature of the sacraments by setting aside the longing for reality's transparence, accepting the unknowing signaled by the withdrawal of signified reality while, nevertheless, responding to that reality's presence with bold creativity. Such is the hermeneutic way "inseparable from us," which is not a pre-determined path with a treasure at its end; rather, "the treasure is nothing else but the work of journeying which takes place in ourselves, the labor of giving birth to ourselves since it is we ourselves who are being plowed ... and who are bearing fruit by becoming different" (p. 54). It operates in the register of symbolic representation, in which we take up the semantic nexus, not as an instrument for control over reality, but as something like the Israelites' desert manna: "a question ... a non-thing ... a non-value" (p. 45), an occasion for transformative encounter with God and neighbor.

Chauvet's sacramental paradigm has been met by skeptics who flag the potential of fideism or self-constructed fantasy in a hermeneutic way "inseparable from us." Lieven Boeve, for instance, voices reservations regarding Chauvet's emphasis on the "absence" of what is signified, expressing concern that such a construal of reality renders sacramental ritual too mysterious to bear real meaning for its adherents. The epistemic results, he fears, could entail faith-communities' resorting to radical particularity or false universalism (here reminding us of Chauvet's worries over Barth's theologizing). Boeve accordingly wonders if Chauvet should develop what he calls "a more appropriate language to express Christ's sacramental presence in the church" (p. 14). A similar concern is evidenced in Elbatrina Clauteaux's effort to accept the tenets of Chauvet's hermeneutic way "inseparable from us" while articulating a more detailed account of sacramental presence. She employs a notion of symbol as dancing between logos and bios, "feed[ing] on the capacity of the cosmos to show its order" (Clauteaux 2008, p. 169). That capacity is evidenced in the phenomenon of interlocutors joining in dialogical relationship regardless of difference. Clauteaux thus emphasizes what she takes to be the intrinsic relationship between "the real" and the symbol, envisioning "the real" as spilling over into the "life of the symbolic," even as it (the real) "goes beyond ... discourse" (ibid.). The "absence" Chauvet emphasizes could be understood simply as discourse's inability to contain the fullness of the symbol. In like manner, Clauteaux infers, God becomes present via the sacraments' symbolic life, with the hypostatic union standing as the symbol par excellence.

Chauvet does, in fact, understand the symbol as a kind of meeting place of bios and logos, and so Clauteaux's suggestive description of reality's capacity to disclose itself via the symbol could prove helpful to Chauvet's followers' efforts to image how God becomes present through sacramental media. Clauteaux's project could turn attention away, however, from certain important implications in Chauvet's hermeneutic paradigm: namely, regarding how we offer ourselves to God in the sacramental meeting of logos and bios. ${ }^{18}$ For Chauvet, it is critical that the bios-logos meeting does not entail "the

18 Cf. (Morrill 2009, pp. 116-18)). 
real" (or "the order of subsistent entities," p. 438) simply "knocking up" against us as we attempt to make ordered sense of it via words and rituals. Rather, one might say that the symbol is a kind of "hyperreality": a merging of bios and our creative response to it, which forms a new reality. This is not to claim that Chauvet's understanding of the symbol accords with Jean Baudrillard's definition of the "hyperreal," as a simulation involving the perversion and pretense of reality. ${ }^{19}$ Chauvet understands the symbol's hyperreality as sacramental, rooted in the nature of the Word's incarnation. Much as the divine Word truly took on the flesh it became, incorporating human life into the life of God, the incarnation discloses that the real, ever exceeding hermeneutic construction, also incorporates that construction. Thus, theological interpretation ought to take a way "inseparable from us" because only thus will it cohere with the truth: that we are simultaneously formed by and forming that which we encounter. Because our discursive activity is an "order of the on-going transformation of subjects into believers" of one sort or another (p. 438), we only avoid idolatry when our thinking begins and ends in a kind of intellectual kenosis that "continually requires theology to take a step backwards, a step which both disenthralls it from itself and reopens it" (p. 73). In this posture of self-opening, we can experience truly graced encounter with the infinite.

Chauvet's vision of reality as the arch-sacramental order of "on-going transformation of subjects into believers" resonates with the epistemology Coakley employs in her emphasis that truth-claims are ever informed by extra-rational features of perception, and that Christological reason remains "in via." Also, in Chauvet's paradigm, human semantic improvisation is a risk required by reality's sacramental dynamism; this coheres with Coakley's take on the Spirit-led cosmic unfolding of Sonship, and our participation in that process. Chauvet goes further than Coakley on this account, however, by presenting hermeneutic construction in a way she does not: that is, Coakley discovers autonomy from God as illusory primarily through silent contemplation, while Chauvet cites the same discovery in the nature of language itself, on the condition that its process is taken up as "manna," an occasion of responsive reopening to God and neighbor. ${ }^{20}$ Returning to the sacraments does not, in itself, instrumentally insure that we embrace this fully hermeneutic theological posture. But, as symbolic figures, the sacraments do illumine the arch-sacramentality of Christian existence, and by that light they empower us to live out that arch-sacramentality.

One could say that, in Chauvet's work, the semantic nexus' sacramental potential is anchored in the fact that the symbol's "hyperreality" is born of a discursive encounter between bios and logos-or, more fittingly, Logos and logos-which is akin to love-making as thematized by Irigaray: it entails a "shared outpouring," a "loss of boundary ... of the body, leaving the circle which encloses my solitude to meet in a shared space" (qtd. in Coakley 2013, pp. 317-18). Depending on "the attitude, idolatrous or not, they elicit from us" (Chauvet 1995, p. 43), our semantic constructions either result in the expansion or constriction of our own lives, and the life of the Incarnation itself. Rowan Williams makes use of such an analogy in his renowned essay "The Body's Grace," wherein he contemplates the comparable impulses driving sexual and communicative advances humans make toward one another. In light of those subtle parallels, we may find a key to understanding the sacrament of revelation as a "nuptial" event of our Spirit-led incorporation into Sonship.

\section{Rowan Williams and the Dialogical Occasion as Nuptial Event}

Williams opens his reflections in "The Body's Grace" (2002) with an observation: "Most people know that sexual intimacy is in some ways frightening for them ... that the whole business is

19 See Baudrillard (1994).

20 For Chauvet, manna's fleeting nature invites its recipient into trusting relationship with God and neighbor; it is thus akin to the "presence of the absence" of Christ in the sacramental medium. This absence invites believers to seek Christ in all persons, especially those occupying the forgotten corners of society. Chauvet $(1979,1987)$ engages this idea in two of his untranslated works: Du symbolique au symbole. Essai sur les sacrements (Paris: Le Cerf, 1979), p. 99; and “L'avenir du sacramental," Recherches de science religieuse 75 (1987): 241-66, at 257. 
irredeemably comic, surrounded by so many odd chances and so many opportunities for making a fool of yourself" (p. 310). Williams goes on to draw upon philosopher Thomas Nagel's observation regarding parallel vulnerabilities entailed in seeking sexual connection with another person and in seeking to communicate with an audience. ${ }^{21}$ (p. 65)Specifically, attempts at communication (i.e., "any attempt to share, in language, what something means," p. 312) and sexual advances share a similar process: both are "aroused" by the presence of another with whom one wants to connect, and to whom one must expose that desire in hopes that it is reciprocated. And, indeed, that desire must be reciprocated, if one's effort is to come to fruition. If I initiate this exchange-oriented movement, I find (if I am honest) that "I am no longer in charge of what I am. Any genuine experience of desire leaves me in this position," Williams observes: "I cannot of myself satisfy my wants without distorting or trivializing them" (p. 313). We here find a reflection that complements Chauvet's assessment that our situation within language leaves us anxious for control. That anxiety can be seen as due not only to the elusiveness of assured meaning, but also to the vulnerability enshrouded by communicative efforts: one's hope for others' careful attention, and one's susceptibility to pain in the face of their potential rejection or misunderstanding of what one hopes to say.

Given the vulnerabilities we experience vis-à-vis sexual desire and its expression, it is hardly surprising that, as Williams notes, culture and religion "have devoted enormous energy to the doomed task of getting it right" (ibid.). (One could certainly say the same for communication as well, with another nod to Chauvet and the "short-cut onto-(theo)logical approaches" he decries.) To Williams' mind, the fact that efforts to secure a risk-free approach to sexuality have proven futile is a reality with transcendent implications, for it is not in "getting it right" that one discovers the graced nature of sexual desire and encounter. It is, rather, in the giving and receiving of the realization that one is desired by another. Williams explains:

Grace, for the Christian believer, is a transformation that depends in large part on knowing yourself to be seen in a certain way: as significant, as wanted. The whole story of creation, incarnation, and our incorporation into the fellowship of Christ's body tells us that God desires us, as if we were God, as if we were that unconditional response to God's giving that God's self makes in the life of the Trinity. We are created so that we may be caught up in this, so that we may grow into the wholehearted love of God by learning that God loves us as God loves God. (pp. 311-12)

The economy of grace which Williams here outlines corresponds with a somewhat controversial understanding of our fleshly pleasures, for it is a picture of the human creature before God wherein the creature's joy is a graced end in itself. Such a construal of grace would supplement Chauvet's work, particularly his cautioning against instrumentalized renderings of the sacraments, with the following observation: when we doggedly seek to make our entry-points into "the shared world of language and (in the widest sense!) 'intercourse'" (Williams 2002, p. 312) instrumental to another process, we likely do so because we are overwhelmed by the "possibility not only of pain and humiliation without any clear payoff, but, just as worryingly, of nonfunctional joy—of joy, to put it less starkly, whose material 'production' is an embodied person aware of grace" (p. 318). Otherwise said, when we only make sense of our desire's frustration or fulfillment instrumentally-i.e., as a means to a "productive" end such as the generation of children through married sex, ${ }^{22}$ or the manufacturing of secured knowledge through metaphysical reasoning (or perhaps even Christoform transfiguration afforded via purgative silencing) - we are disposed to overlook the grace of, in itself, the encounter with the (human or divine) other. One does not have to reach far from this observation to Coakley's: that when believers privilege the "linear" type of trinitarian revelation, primarily focusing on the illumined Father-Son relationship,

21 See also a similar discussion in Chauvet (1979), Du symbolique au symbole, p. 65.

22 This is to reference the view that sexual intercourse is justified only by the partners' intention to conceive a child as a result of the union. Williams takes issue with this viewpoint in "The Body's Grace." 
they could miss how "human ecstatic loves (at their best) might ultimately relate to divine ecstatic love: not by any direct emulation of the trinitarian nature, but by the 'interruption' by the Spirit of any merely 'egological' duality inherent in their relationship" (Coakley 2013, p. 318).

Williams holds fast to this surplus economy of grace, along with our need to embrace the vulnerability it induces in us, if we are to learn to see ourselves as belonging to one another and as objects of "the causeless, loving delight of God" (Williams 2002, p. 317). He gives contours to that relationship via the biblical trope of "nuptial" relations between God and humanity. With a doctrine of revelation in mind, one may observe that Williams' use of the nuptial paradigm has little in common with other uses which render the church's "bridal" incorporation into Christ's life as a process of its becoming instrumental to the reproduction of God's self-expressing Word. Williams instead draws upon the observation that "sexuality beyond biological reproduction is the [metaphor] foremost in the biblical use of sexual metaphors for God's relation to humanity" (p. 318). In Hosea, for instance, Williams points out that "God is not the potent male sower of seed but the tormented lover," engaged in "exposing himself to humiliation" before the beloved and straying people: "God is at the mercy of the perceptions of an uncontrolled partner" (ibid.). Similarly, Williams notes that the marital imagery of Ephesians 5, "for all of its blatant assumption of male authority, still insists on the relational and personally creative element" in the nuptial metaphor "without using procreation as a rational or functional justification" (p. 319). The biblical writers repeatedly draw upon sexual imagery that represents the "complex and costly faithfulness" (ibid.) of God's love affair with God's people, rather than punctuating God's straightforwardly reproductive objective with those images.

In this picture of the nature-grace "nuptial" relation which Williams sketches, God's worldly self-disclosure occurs in a manner that wants to be "enlarge[d by] the life of others" (p. 313). That is to say, God's self-expressing Word invokes creative creaturely "collaboration" in determining the meaning of its material life, and the eschatological end of this incorporative process is "nonfunctional joy," productive of persons aware of being desired by another, whereby they may grow into the love of God. Coakley similarly recommends such a picture of divine longing for human self-distinction by way of Pseudo-Dionysius' "daring metaphysical move" of attributing "ecstatic yearning not only to human lovers of God, but also, prototypically, to divine love of creation" (Coakley 2013, p. 314). But Chauvet and Williams illuminate potential to extend the implications of that ekstasis further than Coakley does: by imagining "the cost and the joy" of God's "truly 'ecstatic' attention" to creation as the conditions of sacramental encounter, which also functions as a discursive occasion of mutual self-opening. We now imagine how the unfolding of creation, incarnation, and our Spirit-led incorporation into Sonship entails God desiring us, as a lover longs for the beloved's affections, and as a speaker longs to heard by the addressee: not as by an empty echo-chamber, neatly receiving and reproducing that speech, but as by an authentic other who receives the Word into and responds to it out of her distinctive other-ness; and who longs to be heard in turn, finding in God's responsive presence an occasion of joy. The Spirit indwells the "hyperreal" body of the semantic nexus because God's self-expression wants to be received, enjoyed, and reconstructed by those who are being drawn into the life of Sonship, i.e., who are growing into the devoted love of God.

\section{Conclusions: Toward a Hermeneutics of Nuptial Encounter}

This essay has drawn upon the insights of Sarah Coakley, Louis-Marie Chauvet, and Rowan Williams to propose that the "inspired" relation between human words and God's Word may be understood as both the sacramental circumstance and outcome of a graced, ongoing "nuptial" encounter: a giving and receiving of desire for discursive, delighted relationship between Creator and creature, in which process the Spirit cooperates with humans' improvised expressions of Sonship as it draws them into the life of God. A "hermeneutics of nuptial encounter"-that is, a mode of theological interpretation which honors this sacramental nature of linguistically mediated revelation-clearly cannot replace interpretive efforts trained upon close exegesis of texts, based upon the learning afforded by empirical disciplines. We should think here of the semiotic relation between sign (i.e., that which 
concerns intended reference, or "linear logic") and symbol. The two do not compete-rather, as Chauvet explains it, these concepts represent points in the same continuum of meaning-making, and one is never without some element of the other (see Chauvet 1995, pp. 111-13). For this essay's purposes, the important thing is to recognize that the symbolic is always at play in the creative construction that inevitably informs our construal of "the real." Thus, a "hermeneutics of nuptial encounter" ought to function as a form of discipline trained upon the symbol, which supplements those empirical disciplines concerned with the content of the linguistic sign. If we accept Shults' broad definition of "spirituality" noted at the opening of this essay-that it "deals with the ways in which we interpret and attend to the transformation of our relation to God and our neighbors" (Shults 2007, p. 1) -then we might say that hermeneutics of nuptial encounter begins and ends with spirituality, for it is fully trained upon the transformed relations with God and neighbor that may occur in the midst of our communicative and interpretive efforts. And it is oriented toward a pneumatological-cum-sacramental goal: that is, it is offered as a means for inviting the transfiguring presence of the Holy Spirit, who renders our expressions sacramental by incorporating them into the expanding life of the Word incarnate.

In closing, I propose that engaging in a hermeneutics of nuptial encounter would warrant the reading community committing itself to pursue the following six disciplines: first, setting aside the longing for reality's transparence, accepting the unknowing signaled by the withdrawal of signified reality; second, responding to that reality's presence with hopeful creativity, taking up the semantic nexus, not as an instrument for control over reality, but as an occasion for transformative encounter with God and neighbor; third, bearing in mind that "the authority of the revelatory Word is continually and freshly encountered and expounded-by a 'reason' which is itself in process of disclosure" (Coakley 2013, p. 88). Fourth, the Triune God retains sovereignty in shaping the terms, content, and outcome of this dialogical intermingling - not as a fellow agent, manipulating our responses by restricting our range of activity, but as the very source, context, and destiny of our agential responses. Those responses are, in a sense, the "children" born of our nuptial encounter with the divine, the orienting form of which we find in Christ. Hermeneuts thus discover their semantic categories "inspired," grafted by the Spirit into God's own self-expression.

Fifth, in this paradigm of revelation as sacrament, we must expect that our Spirit-led experience of God's self-disclosure will remain agonistic. Pre-eschaton, we cannot escape the fact that experience of "hyperreal" fusing of the Word and words is heavy laden by the systemic sins that darken perceptions and constrict our living. Thus, sixth and finally, as we are invited to contribute to the Word's incarnate meanings in an improvised sequence of answerable acts, we have also been given the ongoing task of discerning the profound yet subtle difference between our interpretations' capacities to expand one another's meanings and lives, and their capacities merely to project our desires upon each other (as "texts") and upon texts themselves, flattening their dimensions by treating them as voiceless objects. The first sort of expression is offered for returning response, out of desire for the joy and expression of the "other." It will go to the cross for that offer. The latter sort desires an audience only so as to ensure the speaker's security over or within the corporate network; such is the character of subjugation or enmeshment, both of which abdicate genuine responsibility vis-à-vis one's dialogue partners. Chauvet thus does well to remind us that the manner in which we construct our discourses-evidenced in "the attitude, idolatrous or not, they elicit from us"-either forms or deforms our experience of the sacramental meeting places in creation. The spiritual mishandling of interpretation occurs when we fail to embrace it as an occasion for offering ourselves to be reconstructed by God's and one another's reception and response. ${ }^{23}$ As befits all sacraments, points of the overlap of or distinction between human signifiers and the divine Word remain obscure. Nonetheless, in this occasion of encounter with

23 From this perspective of grace, Williams says, "sexual 'perversion' is sexual activity without risk ... [it is] the effort to bring my happiness back under my control and to refuse to let my body be recreated by another person's perception" (p. 314). 
God, we are offered the grace of receiving that obscuring, not first as an indication of human sin and ignominy, but rather of our being God's beloved children.

Funding: This research received no external funding.

Conflicts of Interest: The author declares no conflict of interest.

\section{References}

Baudrillard, Jean. 1994. Simulacra \& Simulation. Translated by Sheila Faria Glaser. Ann Arbor: University of Michigan Press.

Boeve, Lieven. 2008. Theology in a Postmodern Context and the Hermeneutical Project of Louis-Marie Chauvet. In Sacraments: Revelation of the Humanity of God. Edited by Philippe Bordeyne and Bruce T. Morrill. Collegeville: Liturgical Press, pp. 5-24.

Chauvet, Louis-Marie. 1979. Du symbolique au symbole. Essai sur les sacrements. Paris: Éditions du Cerf, p. 99.

Chauvet, Louis-Marie. 1987. L'avenir du sacramental. Recherches de science religieuse 75: 241-66.

Chauvet, Louis-Marie. 1995. Symbol and Sacrament: A Sacramental Reinterpretation of Christian Existence. Colledgeville: Liturgical Press.

Clauteaux, Elbatrina. 2008. When Anthropologist Encounters Theologian: The Eagle and the Tortoise. In Sacraments: Revelation of the Humanity of God. Edited by Philippe Bordeyne and Bruce T. Morrill. Collegeville: Liturgical Press, pp. 155-70.

Coakley, Sarah. 2002. Powers and Submissions: Spirituality, Philosophy and Gender. Malden: Blackwell Publishing.

Coakley, Sarah. 2009. Is There a Future for Gender and Theology? On Gender, Contemplation, and the Systematic Task. Criterion 47: 52-61.

Coakley, Sarah. 2013. God, Sexuality, and the Self. Cambridge: Cambridge University Press.

Irigaray, Luce. 1991. Questions to Emmanuel Lévinas: On the Divinity of Love. In Re-Reading Lévinas. Edited by Robert Bernasconi and Simon Critchley. London: Athlone.

McCool, Gerald A. 2002. From Unity to Pluralism: The Internal Evolution of Thomism. Oxford: Blackwell.

Moore, Dom S. 1977. Some Principles for an Adequate Theism. The Downside Review 95: 201-13. [CrossRef]

Morrill, Bruce T. 2009. Divine Worship and Human Healing: Integral Theology at the Margins of Life and Death. Collegeville: Liturgical Press.

Shults, LeRon. 2007. Current Trends in Pneumatology. Paper presented at Nordic Systematic Theology Conference, Copenhagen, Denmark, January 4-7.

Stolz, Anselm. 2001. Mystical experience. In The Doctrine of Spiritual Perfection. Translated by Aidan Williams. New York: The Crossroad Publishing Company. First published 1938.

White, Lauren S. 2016. For Comparative Theology's Christian Skeptics: An Invitation to Kenotic Generosity in the Religiously Pluralistic Situation. The Harvard Theological Review 109: 159-77. [CrossRef]

Williams, Rowan D. 2002. The Body's Grace. In Theology and Sexuality: Classic and Contemporary Readings. Edited by Eugene F. Rogers Jr. Oxford: Blackwell Publishers, pp. 309-21.

(C) 2019 by the author. Licensee MDPI, Basel, Switzerland. This article is an open access article distributed under the terms and conditions of the Creative Commons Attribution (CC BY) license (http://creativecommons.org/licenses/by/4.0/). 